\title{
Horizontal Spread of Ilarviruses in Young Trees of Several Peach Cultivars
}

J. K. Uyemoto, United States Department of Agricultural-Agricultural Research Service, and L. R. Bulluck, III, Department of Plant Pathology, University of California, Davis 95616; Sarah Pethybridge, University of Tasmania-North West Centre, Burnie, Tasmania, 7320, Australia; Bruce McCorkell, Department of Primary Industries, Water and Environment, New Town, Tasmania, 7001, Australia; and W. K. Asai, (formerly) University of California Cooperative Extension, Stanislaus County, Modesto 95358

\begin{abstract}
Uyemoto, J. K., Bulluck, L. R., III, Pethybridge, S., McCorkell, B., and Asai, W. K. 2003. Horizontal spread of ilarviruses in young trees of several peach cultivars. Plant Dis. 87:75-77.

Natural spread of Prune dwarf virus (PDV) and Prunus necrotic ring-spot virus (PNRSV) was monitored among healthy trees of six peach (Prunus persica (L.) Batsch) cultivars interplanted into a mature peach orchard between virus-infected trees of the cultivar Carson. Spread of PDV to a few trees of cvs. Andross, Carson, and Halford occurred during bloom just after the dormant test trees were planted in the orchard, as indicated by serological and biological assays during the next season. In contrast, virus infections in cvs. Dr. Davis, Loadel, and Ross were not detected until the fourth to sixth growing seasons. By the seventh season, cumulative transmissions for PDV and PNRSV were 41 and 9, respectively, which included double virus infections in five test trees. Significant differences in cumulative transmission of PDV but not of PNRSV occurred by the fourth season $(P=0.0020)$. Overall, virus infections among the six cultivars ranged from 70 to $100 \%$.
\end{abstract}

Additional keywords: horizontal spread, peach stunt disease, Prune dwarf virus, Prunus necrotic ring spot virus

In a study investigating the spread of two ilarviruses in neighboring 'Carson' peach (Prunus persica (L.) Batsch) orchards, a curious pattern of spread was observed (9). Early in that study, newly infected trees were clustered in closer proximity to the neighboring block of diseased Carson trees than to an adjacent row of diseased nectarine ( $P$. persica (L.) Batsch var. nucipersica (Suckow) C. K. Schneid.) trees. This pattern suggested that spread of both Prune dwarf virus (PDV) and Prunus necrotic ringspot virus (PNRSV), a virus combination known to induce peach stunt disease (PSD), may occur more often between trees and orchards of the same cultivar.

Wagnon et al. (11) also found a similar unidirectional spread pattern from 1952 to 1957 in a 14-acre (5.7-ha) orchard with four peach cultivars. They observed a greater increase in the incidence of PSD within the cultivar Paloro (where PSD was

Corresponding author: J. K. Uyemoto

E-mail: jkuyemoto@ucdavis.edu

Research was supported in part by funds provided by the California Cling Peach Advisory Board and the California Fruit Tree, Nut Tree, and Grapevine Improvement Advisory Board.

Accepted for publication 3 September 2002.

Publication no. D-2002-1118-04R

(C) 2003 The American Phytopathological Society initially found) than in closely adjoining blocks of 'Libbee' and 'Johnson' peaches.

Both studies implied that tree-to-tree spread of PDV and PNRSV was more frequent between the same cultivars and less so between different ones. We tested this hypothesis in a Carson peach orchard, where the incidence of diseased trees was high. Six peach cultivars including, Carson, were planted in the orchard in five completely replicated blocks. The results of this study are reported.

\section{MATERIALS AND METHODS}

Peach cultivars and plot design. In January 1991, dormant nursery trees (colPrunus necrotic ringspot virus (PNRSV) ${ }^{\mathrm{a}}$ procedures were completed in 1991). (numerator) or PNRSV (denominator).

c One tree with PDV and PNRSV.

$\mathrm{d}$ Two trees with PDV and PNRSV. lectively referred to as test trees) of peach cvs. Andross, Carson, Dr. Davis, Halford, Loadel, and Ross were transplanted $0.3 \mathrm{~m}$ apart using two test trees per cultivar interplanted between PSD-affected peach trees in a commercial Carson peach orchard in Hughson, CA. The test trees were planted in a randomized complete block design with five replications and two test trees per cultivar in each replication. To encourage flowering in the initial season of growth (i.e., 1991), test trees were not pruned.

Virus assays. Annually from 1991 to 1997, at or near pink bud stage, shoots were collected and bud extracts (9) of all test trees and a few PSD-infected Carson trees (as virus-infected controls located in the same orchard) were assayed by enzymelinked immunosorbent assays (ELISA; 9). Healthy peach trees grown at University of California, Davis, served as negative controls. Also, at midsummer, three mature shoots per test tree were removed and a bud chip from each was inserted beneath the bark flap on the indicator tree 'Shirofugen' flowering cherry $(P$. serrulata Lindl.). These assays included diseased and healthy tree sources. Following 5 to 6 weeks of incubation, the bark area surrounding the bud chips was sliced open and examined for tissue necrosis. All infected test trees, confirmed by both assays, were removed prior to the next bloom season to eliminate them as potential diseased pollen sources. Removed test trees were not replaced.

Table 1. Horizontal virus spread among test trees of six peach cultivars planted in a commercial 'Carson' peach orchard with a high incidence of trees infected by Prune dwarf virus (PDV) and

\begin{tabular}{lcccccc}
\hline & \multicolumn{6}{c}{ Cumulative infections by PDV/PNRSV } \\
\cline { 2 - 7 } Cultivar & $\mathbf{1 9 9 2}$ & $\mathbf{1 9 9 3}$ & $\mathbf{1 9 9 4}$ & $\mathbf{1 9 9 5}$ & $\mathbf{1 9 9 6}$ & $\mathbf{1 9 9 7}$ \\
\hline Andross & $2 / 0$ & $2 / 0$ & $4 / 1^{\mathrm{c}}$ & $4 / 1$ & $4 / 1$ & $6 / 1$ \\
Carson & $3 / 0$ & $4 / 0$ & $6 / 0$ & $8 / 1^{\mathrm{c}}$ & $9 / 1$ & $1 / 1$ \\
Dr. Davis & $0 / 0$ & $0 / 0$ & $1 / 0$ & $2 / 0$ & $2 / 1$ & $6 / 1$ \\
Halford & $1 / 0$ & $1 / 0$ & $4 / 1^{\mathrm{c}}$ & $5 / 1$ & $5 / 1$ & $8 / 1$ \\
Loadel & $0 / 0$ & $0 / 0$ & $0 / 0$ & $4 / 3^{\mathrm{d}}$ & $4 / 3$ & $5 / 3$ \\
Ross & $0 / 0$ & $0 / 0$ & $0 / 0$ & $0 / 0$ & $0 / 1$ & $6 / 2$ \\
\hline
\end{tabular}

a Plot established in 1991 with two trees of each cultivar per replicate and all trees were negative by enzyme-linked immunosorbent assay (ELISA) and Shirofugen flowering cherry index (both test

$\mathrm{b}$ Assay year and viruses detected by ELISA. Values indicate number of test trees infected with PDV 
Statistical design and analysis. The experiment was set up as a randomized complete block design with five replicates each with two test trees of each of the six cultiplished on a yearly basis in six successive growing seasons. All analyses were conducted using proc GLM in SAS 8.0 (SAS Institute, Cary, NC).

Initially, all test trees assayed negative for PDV and PNRSV by ELISA and Shirofugen indexing. However, assays of vars. Repeated measurements were accom-

\section{RESULTS}

the same test trees in 1992 identified PDV infections in $20 \%$ of Andross, $30 \%$ of Carson, and $10 \%$ of Halford trees, indicating that tree-to-tree spread occurred in the 1991 bloom period (Tables 1 and 2; Fig. 1). In three other cultivars, detection of PDV, PNRSV, or both infections occurred in test trees beginning in 1994: one tree of Dr. Davis in 1994, five trees of Loadel in 1995, and one tree of Ross in 1996.

All infected trees initially were identified by ELISA and later by Shirofugen indexing, with one exception, a test tree of

Table 2. Selected analysis of variance of Prune dwarf virus infections with contrasts for each year to the first year of the experiment

\begin{tabular}{lrcc}
\hline Source $^{\mathbf{a}}$ & df & $\boldsymbol{F}$ value & $\boldsymbol{P}$ value \\
\hline Cultivar & 5 & 3.73 & 0.0151 \\
Year & 5 & 44.39 & $<0.0001$ \\
Year $\times$ cultivar & 25 & 35.94 & $<0.0001$ \\
Tree within cultivar & 6 & 2.03 & 0.1014 \\
Contrasts & & & \\
1992 versus 1993 & 1 & 0.10 & 0.7507 \\
1992 versus 1994 & 1 & 3.74 & 0.0675 \\
1992 versus 1995 & 1 & 12.56 & 0.002 \\
1992 versus 1996 & 1 & 14.95 & 0.001 \\
1992 versus 1997 & 1 & 87.3 & $<0.0001$ \\
\hline
\end{tabular}

a Analysis of variance derived from proc GLM of SAS 8.0 (SAS Institute, Cary, NC).

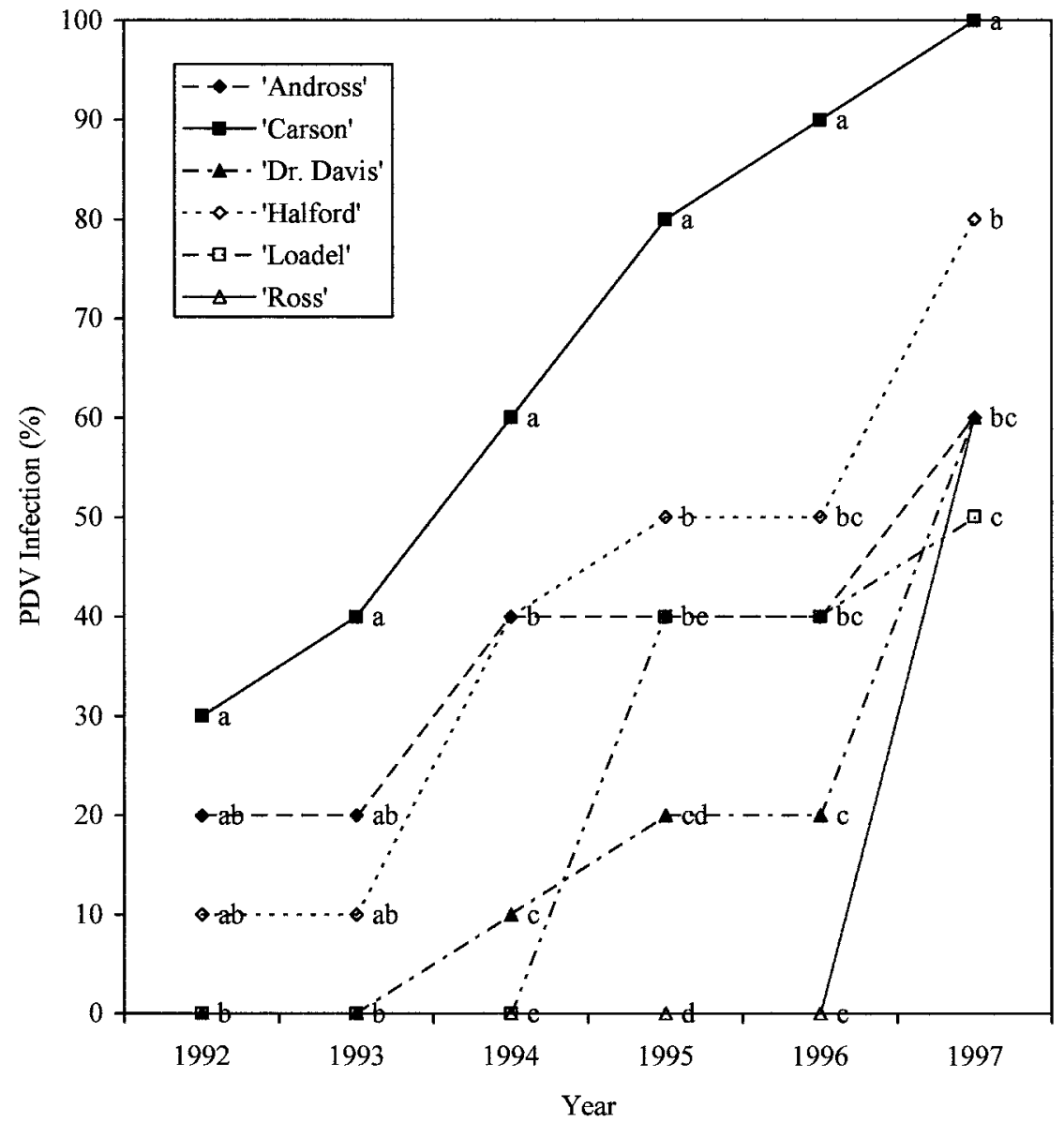

Fig. 1. Percent cumulative infections of Prune dwarf virus (PDV) in six peach cultivars planted in a commercial 'Carson' orchard over seven growing seasons. In 1991, all test trees were healthy. Points with different letters on a given date are significantly different $(P<0.05$, least significant difference is $14.62 \%$ ).
Carson assayed positive by Shirofugen indexing in 1992. A year later, the same tree tested positive for PDV by ELISA and was destroyed. By 1995, cumulative infections of PDV occurred in $80 \%$ of Carson trees, $50 \%$ of Halford, $40 \%$ of Andross and Loadel, and $20 \%$ of Dr. Davis (Table 1; Fig. 1). In contrast, Ross trees tested negative for PDV through assays done in 1996 (Table 1; Fig. 1).

Individual virus transmissions of the 60 test trees totaled 41 for PDV and 9 for PNRSV; of these, double virus infections were detected in one tree each of Andross, Halford (both in 1994), and Carson (1995) and two trees of Loadel (1995). Analyses of variance for the data are provided in Table 2.

\section{DISCUSSION}

In the mid-1960s, tree-to-tree transmissions of PDV (also known as Sour cherry yellows virus) and PNRSV via infected pollen were reported $(3,4)$. Mechanistically, virus transmission in orchard trees was being ascribed to infections in a venereal fashion (i.e., during the pollinationfertilization process). However, others also have demonstrated that infected seed or seedlings (produced when cross-pollinated with diseased pollen source) were obtained from known virus-free seed parents, which continued to remain healthy $(5,8,10,12)$. This suggests that venereal (virus) transmissions were, at best, highly inefficient or that virus infections in a parent tree were yet to be determined.

More recently, transmission of PDV and PNRSV by western flower thrips, Frankliniella occidentalis (Pergande), was demonstrated experimentally (6). Thus, horizontal (virus) transmission among Prunus trees is now being envisioned as follows: winged insects (e.g., honeybees, Apis mellifera L.) transport infected pollen to healthy trees and contaminate the floral tissues while foraging blooms. Virus inoculations by thrips appear to be mechanical in nature (i.e. while feeding on pollen grains, causing its cytoplasmic contents to leak out and invade feeding wounds on the interior surfaces of the flowers; 6,7). We previously had placed infected pollen grains onto carborundum-dusted cotyledons of cucumber (Cucumis sativus L.) seedlings and rubbed them with a pestle, resulting in infections by PDV and PNRSV. Similar exercises with pollen collected from other trees, which were negative for PDV and PNRSV, were done and plants remain healthy (J. K. Uyemoto, unpublished data).

In the Carson peach orchard, extracts of honeybees contaminated with viable pollen grains tested positive for both viruses (9). Other assays of honeybees collected in other peach and prune orchards gave similar results (J. K. Uyemoto, unpublished data). In the course of this study, western 
flower thrips were observed in the peach trees; however, their potential role in virus spread was not considered then and, hence, not investigated.

An earlier report documented rapid intra- and interorchard spread of PDV and PNRSV in neighboring Carson peach orchards (9). Rapid spread of both viruses also was found in a commercial orchard of Andross peach (J. K. Uyemoto, unpublished data). In the present study, 1991 infections by PDV in Andross, Carson, and Halford became apparent in 1992 assays. In contrast, initial infections in three other cultivars were detected in 4- to 6-year-old trees.

Analyses of the data provide statistical evidence that the same (Carson) and like cultivars (Andross and Halford) were prone to earliest virus infections, especially by PDV. Even so, after 1993, clear statistical differences $(P<0.05)$ between test trees of Carson and all others in our study in incidence of PDV infections were apparent (Fig. 1).

Assuming that western flower thrips were ubiquitous throughout the test plot and indiscriminate in colonizing peach cultivars, it appears that cross-contamination of diseased Carson pollen to first-leaf test trees of Carson was due to the attractiveness of flower scent or form, shape, and color of its petals to lure the honeybees $(1,2)$, which had been observed in abundance (J. K. Uyemoto unpublished data). Also, Carson produces showy flowers, whereas Andross, Dr. Davis, and Loadel flowers do not (Tom Gradziel, Prunus breeder, University of California, Davis, personal communication). Even so, Andross and Halford, regarded as nonshowy, had two and one infected tree in 1991, which may have been anomalies. The flower of Ross also is showy, but it is earliest to bloom (among the six cultivars) and, therefore, less likely to be contaminated by Carson pollen, albeit in very young trees and limited blooms. Eventually, however, as trees enlarged and developed extensive fruit-bearing limbs and abundant floral units, ample opportunities for cross contamination and virus transmissions would be afforded in mature, bearing trees. This apparently was realized in our plot.

Although beehives are not purposely used in peach orchards, they are necessary in almonds, an obligate crosspollinated species. Hence, under California conditions where almond and peach orchards can coexist, total exclusion of honeybees in neighboring peach orchards would be impossible. Under these circumstances, one control strategy to at least delay virus spread into young peach orchards (located in close proximity to diseased ones) may be to plant a different peach cultivar. Based in part on our results, orchardists should avoid planting the same or like cultivars near an infected orchard. Even though all six cultivars eventually proved susceptible to horizontal transmissions via a single infected pollen source (i.e., cv. Carson), there was a delay of 2 years and more in virus transmissions to three of the test cultivars. This time lapse would allow healthy trees to develop permanent scaffold branches, fruit-bearing limbs, and realize expected yield potentials before onset of disease symptoms.

\section{ACKNOWLEDGMENTS}

We thank Dave Wilson Nursery for its gift of test trees.
LITERATURE CITED

1. Free, J. R. 1960. The pollination of fruit trees. Bee World 41(6): 141-151.

2. Free, J. R. 1960. The pollination of fruit trees. Bee World 41(7):169-185.

3. George, J. A., and Davidson, T. R. 1964. Further evidence of pollen transmission of necrotic ringspot and sour cherry yellows viruses in sour cherry. Can. J. Plant Sci. 44:383-384.

4. Gilmer, R. M. 1965. Additional evidence of tree-to-tree transmission of sour cherry yellows virus by pollen. Phytopathology 55:482-483.

5. Gilmer, R. M., and Way, R. D. 1961. Pollen transmission of necrotic ringspot and prune dwarf viruses in cherry. Tidsskr. Planteavl. 65:111-117.

6. Greber, R. S., Teakle, D. S., and Mink, G. I. 1992. Thrips-facilitated transmission of Prune dwarf and Prunus necrotic ringspot viruses from cherry pollen to cucumber. Plant Dis. 76:1039-1041.

7. Mink, G. I. 1983. The possible role of honeybees in long-distance spread of Prunus necrotic ringspot virus from California into Washington sweet cherry orchards. Pages $85-$ 91 in: Plant Virus Epidemiology. R. T. Plumb and J. M. Tresh, eds. Blackwell Scientific Publications, Oxford.

8. Mink, G. I. 1992. Ilarvirus vectors. Adv. Dis. Vector Res. 9:261-281.

9. Uyemoto, J. K., Asai, W. K., and Luhn, C. F. 1992. Ilarviruses: evidence for rapid spread and effects on vegetative growth and fruit yields of peach trees. Plant Dis. 76:71-74.

10. Uyemoto, J. K., and Connell, J. H. 1992. Evidence against tree-to-tree transmission of ilarviruses during pollination of two obligately cross-pollinated Prunus species. (Abstr.) Phytopathology 82:1083.

11. Wagnon, H. K., Breece, J. R., Williams, H. E. and Rosenberg, D. Y. 1960. Observations on the natural spread of the so-called peach stunt virus in a California peach orchard. Plant Dis. Rep. 44:488-490.

12. Williams, H. E., Jones, R. W., Traylor, J. A. and Wagnon, H. K. 1970. Passage of necrotic ringspot virus through almond seeds. Plant Dis. Rep. 54:822-824. 